\title{
Developing New Small Molecular Drugs for Prostate Cancer Therapy
}

\author{
Tzu-Min Chan ${ }^{1,2 *}$, Horng-Jyh Harn ${ }^{3,4^{*}}$, Tzyy-Wen Chiou ${ }^{5}$, Shinn-Zong Lin $^{1,6,7,8 \#}$ \\ ${ }^{1}$ Neuropsychiatry Center, China Medical University Hospital, Taichung, Chinese Taipei; ${ }^{2}$ Everfront Biotech Inc., New Taipei City, \\ Chinese Taipei; ${ }^{3}$ Department of Pathology, China Medical University Hospital, Taichung, Chinese Taipei; ${ }^{4}$ Department of Medicine, \\ China Medical University, Taichung, Chinese Taipei; ${ }^{5}$ Department of Life Science and Graduate Institute of Biotechnology, National \\ Dong Hwa University, Hualien, Chinese Taipei; ${ }^{6}$ Department of Neurosurgery, China Medical University Beigan Hospital, Yunlin, \\ Chinese Taipei; ${ }^{7}$ Department of Neurosurgery, Tainan Municipal An-Nan Hospital-China Medical University, Tainan, Chinese \\ Taipei; ${ }^{8}$ Graduate Institute of Immunology, China Medical University, Taichung, Chinese Taipei. \\ Email: "shinnzong@yahoo.com.tw
}

Received February $27^{\text {th }}, 2013$; revised March 29 , $^{\text {th }}$ 2013; accepted April $5^{\text {th }}, 2013$

Copyright (c) 2013 Tzu-Min Chan et al. This is an open access article distributed under the Creative Commons Attribution License, which permits unrestricted use, distribution, and reproduction in any medium, provided the original work is properly cited.

\begin{abstract}
Most of the early prostate cancer has no obvious symptoms, but its malignancy metastasis will cause largely deaths. The treatment options for patients with prostate cancer include traditional surgery, external beam therapy, hormone therapy, small molecular drug and cryosurgery. It was considered non-traditional treatments also can be used in alternative medicines for prostate cancer therapy. There are well-known molecular mechanisms and their pathogenesis, which provide potential targets for drug screening on the prostate cancer. Currently, natural plant extracts or human tissues active ingredients are widely used for the treatment of cancer. Then isolated effective substances in the extract, and further prepared large amounts of small molecule drugs by chemical synthesis. In this review, we summarized four small molecular drugs, abiraterone, docetaxel, isochaihulactone and butylidenephthalide, and their detailed anti-tumor mechanisms. These indicate that small molecular drug is a very efficient way and can be used for prostate cancer treatment.
\end{abstract}

Keywords: Prostate Cancer; Small Molecular Drugs; Abiraterone; Docetaxel; Isochaihulactone; Butylidenephthalide

\section{Introduction}

Prostate cancer nearly occurs in the prostate, a gland found in the male reproductive organs, and its carcinogenesis procedures is relative slowly; however, there are cases of aggressive prostate cancer spread more rapidly than others [1-3]. Early prostate cancer has similar symptoms with benign prostatic hyperplasia, including micturition, urination obstacle, hematuria and dysuria [4,5]. Prostate cancer itself does not cause severe symptoms, however, metastatic prostate cancer can spread through body and have fatal symptoms [6].

There are several currently known mechanisms for the prostate cancer pathogenesis [7]. Mutation of P53, common in prostate cancer, influenced its downstream effectors, which have been proved mediating prostate cancer processing and causing aberrant nuclear protein accumu-

\footnotetext{
*Tzu-Min Chan and Horng-Jyh Harn contributed equally to this work. ${ }^{\#}$ Corresponding author.
}

lation [8-10]. Loss of the tumor suppress gene PTEN, implying with advanced prostate tumors in clinically [9,11,12]. The c-met and HER2/neu (c-erbB2) oncogene also play important roles in prostate carcinogenesis [1315]. Besides, RUNX2 can prevent cancer cell leading to apoptosis and contribute in prostate cancer development [16]. Furthermore, androgen signaling involved in development and homeostasis of the prostate, and cancer initiation and progression correlated with activation of androgen receptor $[17,18]$.

Treatments of prostate cancer involved surgery, external beam therapy, hormone therapy, small molecular drug and cryosurgery [19-24]. Currently, natural plant extracts or human tissues active ingredients are widely used for the treatment of cancer, and further isolated effective substances in the extract $[25,26]$. With the advances in drug design and chemical synthesis, small molecule drugs become more popular in drug screening and clinical trial [27]. The small molecular drugs have 
irreplaceable characteristics in easy to chemical synthesis, drug save, oral absorption and molecules modify and design $[28,29]$. In this review, we summarized four kinds of prostate cancer treated small molecular drugs, abiraterone, docetaxel, isochaihulactone and butylidenephthalide [30-33].

\section{Abiraterone}

Androgen receptor, a ligand-inducible transcription factor and member of the steroid hormone, enhance prostate cancer growth and progression through activation of target genes [34,35]. There have been proved that androgen ablation can control metastatic prostate cancer growth through reduction in serum acid phosphatase by surgical or medical castration [36,37]. Escalating studies showed abiraterone play a role in inhibiting of CYP17, a androgen synthesis suppressor, which has potential therapeutic effects in aggressive castration-resistant prostate cancer [38-41]. Abiraterone already is a Food and Drug Administration (FDA) drug used in prostate cancer, extended survival time up to 14.8 months, and its formulation form as abiraterone acetate $[33,42,43]$.

\section{Docetaxel}

Androgen-independent prostate cancer defined as lower levels of testosterone found in tissue during carcinogenesis, it cannot cured by surgery [33,44-46]. Several studies pinpointed precise mechanisms progression and tried to offer new cure for androgen-independent prostate cancer [47-49]. Docetaxel, a member of the taxane family, has been used extensively and treated with many cancers, including breast, ovarian and certain forms of lung cancer $[50,51]$. The mechanism of docetaxel to inhibit prostate cancer is associate with tubulin and then promotes microtubule assembly, this can cause mitotic-dependent cell cycle arrest [52-54]. Further, docetaxel induced cell death through activation of caspase and lysosomal pathways and function as medication drugs for prostate cancer $[55,56]$.

\section{Isochaihulactone}

Previously indicated isochaihulactone, isolating from $\mathrm{Bu}$ pleurum scorzonerifolium or Bursera microphylla, has potential inhibiting ability in A549 cell through cell cycle arrest at the G2/M phase and induced apoptosis [26, 57-59]. Besides, isochaihulactone also can inhibits cell proliferation via downregulation of the checkpoint proteins cdc25c, cyclin B1, and cdc2 in LNCaP cell; resulting in apoptotic death through enhanced p53 and p21 expression [30,59]. The apoptotic signal were controlled by activating EGR-1 and NAG-1 in JNK-dependent manner $[30,60]$. Indicating reduced androgen receptor expression in isochaihulactone treated LNCaP cell $[30,60]$.
These results proved that isochaihulactone may has potential therapeutic efficient for prostate cancer therapy.

\section{Butylidenephthalide}

Butylidenephthalide (BP), isolated from Angelica sinensis, showed a dramatic therapeutic effect in against glioblastoma multiforme and its derivative also inhibit cell growth in hepatocellular carcinoma and lung adenocarcinoma cells [61-63]. Furthermore, butylidenephthalide could inhibit cell proliferation and induce cell death in human prostate cancer cells (PC-3 and LNCaP) [31]. The mechanisms were involved change expression levels of G0/G1 regulatory proteins, its cytotoxicity is mediated by endoplasmic reticulum stress and induction of death receptor pathway [31]. Theses indicated that butylidenephthalide also has potential therapeutic effect in aggressive prostate cancer.

\section{Conclusion}

In this review, we summarized four different small molecular drugs and their therapeutic effects and mechanisms on prostate cancer. Through the analysis of the extracts, which contain anti-tumor ability, we can isolate effective substance and rule out their therapeutic mechanisms. These methods provide a convenient way to find out new potential anti-tumor drugs.

\section{Acknowledgements}

Stem Cell and Regeneration Medicine Foundation, NSC 99-2320-B-039-008-MY3 and Everfront Biotech Inc.

\section{REFERENCES}

[1] L. Bubendorf, A. Schopfer, U. Wagner, G. Sauter, H. Moch, N. Willi, T. C. Gasser and M. J. Mihatsch, "Metastatic Patterns of Prostate Cancer: An Autopsy Study of 1589 Patients,” Human Pathology, Vol. 31, No. 5, 2000, pp. 578-583. doi:10.1053/hp.2000.6698

[2] C. Abate-Shen and M. M. Shen, "Molecular Genetics of Prostate Cancer,” Genes \& Development, Vol. 14, No. 19, 2000, pp. 2410-2434. doi:10.1101/gad.819500

[3] A. M. DeMarzo, W. G. Nelson, W. B. Isaacs and J. I. Epstein, "Pathological and Molecular Aspects of Prostate Cancer,” Lancet, Vol. 361, No. 9361, 2003, pp. 955-964. doi:10.1016/S0140-6736(03)12779-1

[4] C. Taieb and E. Myon, "Benign Prostatic Hyperplasia Recognition of the Consequences of the Pathology for the Spouse," Value in Health, Vol. 6, No. 3, 2003, p. 381. doi:10.1016/S1098-3015(10)64302-1

[5] D. C. Miller, K. S. Hafez, A. Stewart, J. E. Montie and J. T. Wei, "Prostate Carcinoma Presentation, Diagnosis, and Staging: An Update form the National Cancer Data Base,” Cancer, Vol. 98, No. 6, 2003, pp. 1169-1178. doi:10.1002/cncr.11635 
[6] I. W. van der Cruijsen-Koeter, A. N. Vis, M. J. Roobol, M. F. Wildhagen, H. J. de Koning, T. H. van der Kwast and F. H. Schroder, "Comparison of Screen Detected and Clinically Diagnosed Prostate Cancer in the European randomized Study of Screening for Prostate Cancer, Section Rotterdam,” Journal of Urology, Vol. 174, No. 1, 2005, pp. 121-125.

doi:10.1097/01.ju.0000162061.40533.0f

[7] C. R. Dowling and G. P. Risbridger, "The Role of Inhibins and Activins in Prostate Cancer Pathogenesis," Endocrine-Related Cancer, Vol. 7, No. 4, 2000, pp. 243256. doi:10.1677/erc.0.0070243

[8] F. J. Meyers, P. H. Gumerlock, S. G. Chi, H. Borchers, A. D. Deitch and R. W. deVere White, "Very Frequent p53 Mutations in Metastatic Prostate Carcinoma and in Matched Primary Tumors," Cancer, Vol. 83, No. 12, 1998, pp. 2534-2539. doi:10.1002/(SICI)1097-0142(19981215)83:12<2534::AI D-CNCR19>3.0.CO;2-V

[9] B. C. Leibovich, L. Cheng, A. L. Weaver, R. P. Myers and D. G. Bostwick, "Outcome Prediction with p53 Immunostaining after Radical Prostatectomy in Patients with Locally Advanced Prostate Cancer," Journal of Urology, Vol. 163, No. 6, 2000, pp. 1756-1760. doi:10.1016/S0022-5347(05)67536-2

[10] D. I. Quinn, S. M. Henshall, D. R. Head, D. Golovsky, J. D. Wilson, P. C. Brenner, J. J. Turner, W. Delprado, J. F. Finlayson, P. D. Stricker, et al., "Prognostic Significance of p53 Nuclear Accumulation in Localized Prostate Cancer Treated with Radical Prostatectomy," Cancer Research, Vol. 60, No. 6, 2000, pp. 1585-1594.

[11] P. Cairns, K Okami, S. Halachmi, N. Halachmi, M. Esteller, J. G. Herman, J. Jen, W. B. Isaacs, G. S. Bova and D. Sidransky, "Frequent Inactivation of PTEN/ MMAC1 in Primary Prostate Cancer," Cancer Research, Vol. 57, No. 22, 1997, pp. 4997-5000.

[12] B. Nan, T. Snabboon, E. Unni, X. J. Yuan, Y. E. Whang and M. Marcelli, "The PTEN Tumor Suppressor Is a Negative Modulator of Androgen Receptor Transcriptional Activity," Journal of Molecular Endocrinology, Vol. 31, No. 1, 2003, pp. 169-183. doi:10.1677/jme.0.0310169

[13] L. L. Pisters, P. Troncoso, H. E. Zhau, W. Li, A. C. von Eschenbach and L. W. Chung, "c-Met Proto-Oncogene Expression in Benign and Malignant Human Prostate Tissues,” Journal of Urology, Vol. 154, No. 1, 1995, pp. 293298. doi:10.1016/S0022-5347(01)67297-5

[14] B. S. Knudsen, G. A. Gmyrek, J. Inra, D. S. Scherr, E. D. Vaughan, D. M. Nanus, M. W. Kattan, W. L. Gerald and G. F. Vande Woude, "High Expression of the Met Receptor in Prostate Cancer Metastasis to Bone," Urology, Vol. 60, No. 6, 2002, pp. 1113-1117. doi:10.1016/S0090-4295(02)01954-4

[15] K. J Savinainen, O. R. Saramaki, M. J. Linja, O. Bratt, T. L. Tammela, J. J. Isola and T. Visakorpi, "Expression and Gene Copy Number Analysis of ERBB2 Oncogene in Prostate Cancer," American Journal of Pathology, Vol. 160, No. 1, 2002, pp. 339-345. doi:10.1016/S0002-9440(10)64377-5
[16] J. Akech, J. J. Wixted, K. Bedard, M. van der Deen, S. Hussain, T. A. Guise, A. J. van Wijnen, J. L. Stein, L. R. Languino, D. C. Altieri, et al., "Runx2 Association with Progression of Prostate Cancer in Patients: Mechanisms Mediating Bone Osteolysis and Osteoblastic Metastatic Lesions,” Oncogene, Vol. 29, No. 6, 2010, pp. 811-821. doi:10.1038/onc.2009.389

[17] P. E. Lonergan and D. J. Tindall, “Androgen Receptor Signaling in Prostate Cancer Development and Progression,” Journal of Carcinogenesis, Vol. 10, 2011, p. 20. doi:10.4103/1477-3163.83937

[18] R. Foley, D. Hollywood and M. Lawler, "Molecular Pathology of Prostate Cancer: The Key to Identifying New Biomarkers of Disease,” Endocrine-Related Cancer, Vol. 11, No. 3, 2004, pp. 477-488. doi:10.1677/erc.1.00699

[19] T. M. Pisansky, S. S. Cha, J. D. Earle, E. D. Durr, T. F. Kozelsky, H. S. Wieand and J. E. Oesterling, "Prostate-Specific Antigen as a Pretherapy Prognostic Factor in Patients Treated with Radiation Therapy for Clinically Localized Prostate Cancer,” Journal of Clinical Oncology, Vol. 11, No. 11, 1993, pp. 2158-2166.

[20] J. C. Carlton, G. K. Zagars and M. J. Oswald, “The Role of Serum Prostatic Acid Phosphatase in the Management of Adenocarcinoma of the Prostate with Radiotherapy,” International Journal of Radiation Oncology*Biology* Physics, Vol. 19, No. 6, 1990, pp. 1383-1388. doi:10.1016/0360-3016(90)90348-N

[21] A. L. Zietman, J. J. Coen, W. U. Shipley, C. G. Willett and J. T. Efird, "Radical Radiation Therapy in the Management of Prostatic Adenocarcinoma: The Initial Prostate Specific Antigen Value as a Predictor of Treatment Outcome,” Journal of Urology, Vol. 151, No. 3, 1994, pp. 640-645.

[22] V. B. Shahinian, Y. F. Kuo, J. L. Freeman and J. S. Goodwin, "Risk of Fracture after Androgen Deprivation for Prostate Cancer," The New England Journal of Medicine, Vol. 352, No. 2, 2005, pp. 154-164. doi:10.1056/NEJMoa041943

[23] D. R. Berthold, G. R. Pond, F. Soban, R. de Wit, M. Eisenberger and I. F. Tannock, "Docetaxel plus Prednisone or Mitoxantrone plus Prednisone for Advanced Prostate Cancer: Updated Survival in the TAX 327 Study," Journal of Clinical Oncology, Vol. 26, No. 2, 2008, pp. 242-245. doi:10.1200/JCO.2007.12.4008

[24] M. J. Zelefsky, H. Chan, M. Hunt, Y. Yamada, A. M. Shippy and H. Amols, "Long-Term Outcome of High Dose Intensity Modulated Radiation Therapy for Patients with Clinically Localized Prostate Cancer," Journal of Urology, Vol. 176, No. 4, 2006, pp. 1415-1419. doi:10.1016/j.juro.2006.06.002

[25] S. Nobili, D. Lippi, E. Witort, M. Donnini, L. Bausi, E. Mini and S. Capaccioli, "Natural Compounds for Cancer Treatment and Prevention,” Pharmacological Research, Vol. 59, No. 6, 2009, pp. 365-378. doi:10.1016/j.phrs.2009.01.017

[26] K. Tomioka, T. Ishiguro, Y. Iitaka and K. Koga, "Stereoselective Reactions. XII. Synthesis of Antitumor-Active Steganacin Analogs, Picrosteganol and Epipicrosteganol, by Selective Isomerization," Chemical and Pharmaceuti- 
cal Bulletin (Tokyo), Vol. 34, No. 4, 1986, pp. 1501-1504. doi:10.1248/cpb.34.1501

[27] J. Zhang, P. L. Yang and N. S. Gray, "Targeting Cancer with Small Molecule Kinase Inhibitors,” Nature Reviews Cancer, Vol. 9, No. 1, 2009, pp. 28-39. doi:10.1038/nrc2559

[28] M. Hakanson, S. Kobel, M. P. Lutolf, M. Textor, E. Cukierman and M. Charnley, "Controlled Breast Cancer Microarrays for the Deconvolution of Cellular Multilayering and Density Effects upon Drug Responses,” PLoS One, Vol. 7, No. 6, 2012, Article ID: e40141. doi:10.1371/journal.pone.0040141

[29] G. Szakacs, J. K. Paterson, J. A. Ludwig, C. Booth-Genthe and M. M. Gottesman, "Targeting Multidrug Resistance in Cancer," Nature Reviews Drug Discovery, Vol. 5, No. 3, 2006, pp. 219-234. doi:10.1038/nrd1984

[30] S. C. Chiu, M. J. Wang, H. H. Yang, S. P. Chen, S. Y. Huang, Y. L. Chen, S. Z. Lin, H. J. Harn and C. Y. Pang, “Activation of NAG-1 via JNK Signaling Revealed an Isochaihulactone-Triggered Cell Death in Human LNCaP Prostate Cancer Cells,” BMC Cancer, Vol. 11, 2011, p. 146. doi:10.1186/1471-2407-11-146

[31] S. C. Chiu, S. P. Chen, S. Y. Huang, M. J. Wang, S. Z. Lin, H. J. Harn and C. Y. Pang, "Induction of Apoptosis Coupled to Endoplasmic Reticulum Stress in Human Prostate Cancer Cells by n-Butylidenephthalide," PLoS One, Vol. 7, No. 3, 2012, p. e33742. doi:10.1371/journal.pone.0033742

[32] A. O’Donnell, I. Judson, M. Dowsett, F. Raynaud, D. Dearnaley, M. Mason, S. Harland, A. Robbins, G. Halbert, B. Nutley, et al., "Hormonal Impact of the 17alpha-hydroxylase/C(17,20)-lyase Inhibitor Abiraterone Acetate (CB7630) in Patients with Prostate Cancer,” British Journal of Cancer, Vol. 90, No. 12, 2004, pp. 2317-2325.

[33] M. A. Khan, M. Carducci and A. W. Partin, "The Evolving Role of Docetaxel in the Management of Androgen Independent Prostate Cancer," The Journal of Urology, Vol. 170, No. 5, 2003, pp. 1709-1716. doi:10.1097/01.ju.0000088787.95124.4b

[34] E. M. Wilson, “Androgen Receptor Molecular Biology and Potential Targets in Prostate Cancer," Therapeutic Advances in Urology, Vol. 2, No. 3, 2010, pp. 105-117. doi:10.1177/1756287210372380

[35] N. C. Bennett, R. A. Gardiner, J. D. Hooper, D. W. Johnson and G. C. Gobe, "Molecular Cell Biology of Androgen Receptor Signaling," The International Journal of Biochemistry \& Cell Biology, Vol. 42, No. 6, 2010, pp. 813-827. doi:10.1016/j.biocel.2009.11.013

[36] C. Huggins and C. V. Hodges, "Studies on Prostatic Cancer I. The Effect of Castration, of Estrogen and of Androgen Injection on Serum Phosphatases in Metastatic Carcinoma of the Prostate. 1941," The Journal of Urology, Vol. 168, No. 1, 2002, pp. 9-12. doi:10.1016/S0022-5347(05)64820-3

[37] S. Glina, M. A. Rivero, A. Morales and A. Morgentaler, "Studies on Prostatic Cancer I. The Effect of Castration, of Estrogen and of Androgen Injection on Serum Phosphatases in Metastatic Carcinoma of the Prostate by Charles Huggins and Clarence V. Hodges,” The Journal of Sexual Medicine, Vol. 7, No. 2, 2010, pp. 640-644. doi:10.1111/j.1743-6109.2009.01680.x

[38] M. N. Stein, S. Goodin, R. S. Dipaola, "Abiraterone in Prostate Cancer: A New Angle to an Old Problem,” Clinical Cancer Research, Vol. 18, No. 7, 2012, pp. 1848-1854. doi:10.1158/1078-0432.CCR-11-1805

[39] G. Attard, A. H. Reid, R. A’Hern, C. Parker, N. B. Oommen, E. Folkerd, C. Messiou, L. R. Molife, G. Maier, E. Thompson, et al., "Selective Inhibition of CYP17 with Abiraterone Acetate Is Highly Active in the Treatment of Castration-Resistant Prostate Cancer,” Journal of Clinical Oncology, Vol. 27, No. 23, 2009, pp. 3742-3748. doi:10.1200/JCO.2008.20.0642

[40] H. P. Schmid and D. S. Engeler "Words of Wisdom. Re: Selective Inhibition of CYP17 with Abiraterone Acetate Is Highly Active in the Treatment of Castration-Resistant Prostate Cancer," European Urology, Vol. 56, No. 4, 2009, pp. 744-745. doi:10.1016/j.eururo.2009.07.012

[41] T. S. Vasaitis, R. D. Bruno and V. C. Njar, "CYP17 Inhibitors for Prostate Cancer Therapy," The Journal of Steroid Biochemistry and Molecular Biology, Vol. 125, No. 1-2, 2011, pp. 23-31. doi:10.1016/j.jsbmb.2010.11.005

[42] K. Fizazi, H. I. Scher, A. Molina, C. J. Logothetis, K. N. Chi, R. J. Jones, J. N. Staffurth, S. North, N. J. Vogelzang, F. Saad, et al., "Abiraterone Acetate for Treatment of Metastatic Castration-Resistant Prostate Cancer: Final Overall Survival Analysis of the COU-AA-301 Randomised, Double-Blind, Placebo-Controlled Phase 3 Study," The Lancet Oncology, Vol. 3, No. 10, 2012, pp. 1983-992. doi:10.1016/S1470-2045(12)70379-0

[43] G. Attard, A. H. Reid, T. A. Yap, F. Raynaud, M. Dowsett, S. Settatree, M. Barrett, C. Parker, V. Martins, E. Folkerd, et al., "Phase I Clinical Trial of a Selective Inhibitor of CYP17, Abiraterone Acetate, Confirms That Castration-Resistant Prostate Cancer Commonly Remains Hormone Driven,” Journal of Clinical Oncology, Vol. 26, No. 28, 2008, pp. 4563-4571. doi:10.1200/JCO.2007.15.9749

[44] B. J. Feldman and D. Feldman, "The Development of Androgen-Independent Prostate Cancer," Nature Reviews Cancer, Vol. 1, No. 1, 2001, pp. 34-45. doi:10.1038/35094009

[45] T. M. Beer, A. Myrthue and K. M. Eilers, "Rationale for the Development and Current Status of Calcitriol in Androgen-Independent Prostate Cancer," World Journal of Urology, Vol. 23, No. 1, 2005, pp. 28-32. doi:10.1007/s00345-004-0476-y

[46] K. J. Pienta and D. Bradley, "Mechanisms Underlying the Development of Androgen-Independent Prostate Cancer," Clinical Cancer Research, Vol. 12, No. 6, 2006, pp. 1665-1671. doi:10.1158/1078-0432.CCR-06-0067

[47] P. N. Jr. Lara and F. J. Meyers, “Treatment Options in Androgen-Independent Prostate Cancer,” Cancer Investigation, Vol. 17, No. 2, 1999, pp. 137-144.

[48] T. B. Dorff, R. L. Shazer and E. M. Nepomuceno and S. J. Tucker, "Successful Treatment of Metastatic Andro- 
gen-Independent Prostate Carcinoma in a Transsexual Patient,” Clinical Genitourinary Cancer, Vol. 5, No. 5, 2007, pp.344-346. doi:10.3816/CGC.2007.n.016

[49] S. W. Zhang, S. Y. Zhou, J. C. Shao and X. W. Qu, "Primary Research on Chinese Medicine Treatment of Androgen-Independent Prostate Cancer," Chinese Journal of Integrative Medicine, Vol. 15, No. 3, 2009, pp. 168-169. doi:10.1007/s11655-009-0168-y

[50] N. Turner, J. Stewart, F. Barnett and S. White, "Syndrome of Inappropriate Anti-Diuretic Hormone Secretion Secondary to Carboplatin after Docetaxel-CarboplatinTrastuzumab Combination for Early Stage HER-2 Positive Breast Cancer," Asia-Pacific Journal of Clinical Oncology, Vol. 8, No. 3, 2012, pp. e9-e11. doi:10.1111/j.1743-7563.2012.01526.x

[51] B. Ramaswamy and S. Puhalla, "Docetaxel: A TubulinStabilizing Agent Approved for the Management of Several Solid Tumors,” Drugs Today, Vol. 42, No. 4, 2006, pp. 265-279. doi:10.1358/dot.2006.42.4.968648

[52] D. P. Petrylak, "The Treatment of Hormone-Refractory Prostate Cancer: Docetaxel and Beyond," Reviews in Urology, Vol. 8, Suppl. 2, 2006, pp S48-S55.

[53] C. Dumontet and M. A. Jordan, "Microtubule-Binding Agents: A Dynamic Field of Cancer Therapeutics," Nature Reviews Drug Discovery, Vol. 9, No. 10, 2010, pp. 790-803. doi:10.1038/nrd3253

[54] F. Fabbri, D. Amadori, S. Carloni, G. Brigliadori, A. Tesei, P. Ulivi, M. Rosetti, I. Vannini, C. Arienti, W. Zoli, et al., "Mitotic Catastrophe and Apoptosis Induced by Docetaxel in Hormone-Refractory Prostate Cancer Cells," Journal of Cellular Physiology, Vol. 217, No. 2, 2008, pp. 494-501. doi:10.1002/jcp.21522

[55] M. Mediavilla-Varela, F. J. Pacheco, F. Almaguel, J. Perez, E. Sahakian, T. R. Daniels, L. S. Leoh, A. Padilla, N. R. Wall, M. B. Lilly, et al., "Docetaxel-Induced Prostate Cancer Cell Death Involves Concomitant Activation of Caspase and Lysosomal Pathways and Is Attenuated by LEDGF/p75,” Molecular Cancer, Vol. 8, 2009, p. 68. doi:10.1186/1476-4598-8-68

[56] D. Z. Qian, B. L. Rademacher, J. Pittsenbarger, C. Y. Huang, A. Myrthue, C. S. Higano, M. Garzotto, P. S. Nelson, T. M. Beer, “CCL2 Is Induced by Chemotherapy and Protects Prostate Cancer Cells from Docetaxel-Induced Cytotoxicity," Prostate, Vol. 70, No. 4, 2010, pp. 433-442.

[57] Y. L. Cheng, S. C. Lee, S. Z. Lin, W. L. Chang, Y. L.
Chen, N. M. Tsai, Y. C. Liu, C. Tzao, D. S. Yu and H. J. Harn, “Anti-Proliferative Activity of Bupleurum Scrozonerifolium in A549 Human Lung Cancer Cells in Vitro and in Vivo," Cancer Letters, Vol. 222, No. 2, 2005, pp. 183-193. doi:10.1016/j.canlet.2004.10.015

[58] Y. L. Chen, S. Z. Lin, W. L. Chang, Y. L. Cheng and H. J. Harn, "Requirement for ERK Activation in Acetone Extract Identified from Bupleurum scorzonerifolium Induced A549 Tumor Cell Apoptosis and Keratin 8 Phosphorylation,” Life Sciences, Vol. 76, No. 21, 2005, pp. 2409-2420. doi:10.1016/j.lfs.2004.09.044

[59] Y. L. Chen, P. C. Lin, S. P. Chen, C. C. Lin, N. M. Tsai, Y. L. Cheng, W. L. Chang, S. Z. Lin and H. J. Harn, “Activation of Nonsteroidal Anti-Inflammatory Drug-Activated Gene-1 via Extracellular Signal-Regulated Kinase 1/2 Mitogen-Activated Protein Kinase Revealed a Isochaihulactone-Triggered Apoptotic Pathway in Human Lung Cancer A549 Cells," Journal of Pharmacology and Experimental Therapeutics, Vol. 323, No. 2, 2007, pp. 746-756. doi:10.1124/jpet.107.126193

[60] P. Y. Liu, S. Z. Lin, J. J. Sheu, C. T. Lin, P. C. Lin, Y. W. Chou, M. H. Huang, T. W. Chiou and H. J. Harn, "Regulation of Androgen Receptor Expression by Z-Isochaihulactone Mediated by the JNK Signaling Pathway and Might be Related to Cytotoxicity in Prostate Cancer," Prostate, 2012.

[61] Y. L. Chen, M. H. Jian, C. C. Lin, J. C. Kang, S. P. Chen, P. C. Lin, P. J. Hung, J. R. Chen, W. L. Chang, S. Z. Lin, et al., "The Induction of Orphan Nuclear Receptor Nur77 Expression by $n$-Butylenephthalide as Pharmaceuticals on Hepatocellular Carcinoma Cell Therapy," Molecular Pharmacology, Vol. 74, No. 4, 2008, pp. 1046-1058. doi:10.1124/mol.107.044800

[62] P. C. Lin, Y. L. Chen, S. C. Chiu, Y. L. Yu, S. P. Chen, M. H. Chien, K. Y. Chen, W. L. Chang, S. Z. Lin, T. W. Chiou, et al., "Orphan Nuclear Receptor, Nurr-77 Was a Possible Target Gene of Butylidenephthalide Chemotherapy on Glioblastoma Multiform Brain Tumor," Journal of Neurochemistry, Vol. 106, No. 3, 2008, pp. 1017 1026. doi:10.1111/j.1471-4159.2008.05432.x

[63] C. W. Wei, C. C. Lin, Y. L. Yu, C. Y. Lin, P. C. Lin, M. T. Wu, C. J. Chen, W. Chang, S. Z. Lin, Y. L. Chen, et al., " $n$-Butylidenephthalide Induced Apoptosis in the A549 Human Lung Adenocarcinoma Cell Line by Coupled Down-Regulation of AP-2alpha and Telomerase Activity,” Acta Pharmacologica Sinica, Vol. 30, No. 9, 2009, pp. 1297-1306. doi:10.1038/aps.2009.124 